\title{
PASSIVE (RE)TRANSLATIONS AND IDENTITY STRUGGLES IN THE POETRY OF LEONARD COHEN. A COMPARISON OF THREE TRANSLATIONS OF BOOK OF LONGING (2006)
}

Francis Mus 1

${ }^{1}$ Liège University, University of Leuven, Belgique

\begin{abstract}
Over the course of less than a decade, Leonard Cohen's Book of Longing (2006), was translated into French three different times. The poetry collection of Cohen was first translated in Québec (Livre du constant désir, 2007) and then in France (Le livre du désir, 2008). In addition, seven poems published in Book of Longing previously appeared as songs on the studio album Ten New Songs (2001). The French release of this album was accompanied by a promotional booklet, in which French translations (made by Graeme Allwright) are printed. In this article, the question is raised whether these texts can be labeled as 'retranslations' or not. The three translations will first be compared in order to determine to what extent several power mechanisms have influenced the production of these translations, namely the dynamics between centre and periphery (Paris and Québec) and between highbrow-lowbrow cultural products (literature and music). These external factors will then be compared to a number of internal factors, i.e. a specific interpretation of Cohen's poetry that may have influenced the adopted translation strategies of the three texts under consideration.
\end{abstract}

Keywords: Music and translation; Leonard Cohen; Canadian literature; Retranslation 


\title{
(RE)TRADUÇÕES PASSIVAS E DISPUTAS IDENTITÁRIAS NA POESIA DE LEONARD COHEN: UMA COMPARAÇÃO ENTRE TRÊS TRADUÇÕES DO BOOK OF LONGING (2006)
}

\begin{abstract}
Resumo: Em menos de uma década, o Book of Longing [Livro do desejo] de Leonard Cohen (2006) foi traduzido para o francês três vezes. A coleção de poemas de Cohen foi primeiramente traduzida no Québec (Livre du constant désir, 2007), e então na França (Le livre du désir, 2008). Além disso, sete poemas do Book of Longing apareceram previamente como canções no álbum Ten New Songs [Dez novas canções] (2011). O lançamento francês do álbum foi acompanhado por um libreto promocional, no qual foram impressas traduções para o francês (feitas por Graeme Allwright). Neste artigo, pergunta-se se estes textos podem ser tachados como retraduções ou não. As três traduções serão inicialmente comparadas, para se determinar até que ponto diferentes mecanismos de poder influenciaram a produção destas traduções, a saber: a dinâmica entre centro e periferia (Paris e Québec), e entre produtos de alta e baixa cultura (literatura e música). Estes fatores externos serão então comparados a um certo número de fatores internos, i.e. a interpretação específica da poesia de Cohen que pode ter influenciado as estratégias tradutórias do três textos sob consideração.
\end{abstract}

Palavras-chave: Música e tradução; Leonard Cohen; Literatura canadense; Retradução

\section{Introduction}

"Incompleteness characterizes (re)translation" writes Annie Brisset $(2004,44)$ in her crucial contribution to the debates over the famous Retranslation Hypothesis that was first formulated by Antoine Berman in 1990. According to Brisset, a translation or a series of (re)translations can never be compared unambiguously with the source text. It is difficult to speak about a real evolution of the relation of different translations towards their source text because the original is instable by nature, both on a concrete level (several different 'versions' of a work may coexist, especially in the case of Leonard Cohen - see below) and on a more fundamental 
level (a text is never monosemic but is always co-constructed by the context and the reader). Indeed, Brisset's criticism does not only apply to (re)translation: incompleteness is typical of every construction (idem, 44). Based on the various successive versions of Darwin's On the Origin of Species and the accompanying (re) translations, "the idea of the original text as a unique and stable focus of meaning is profoundly questioned" (idem, 43).

The thesis of Brisset is convincingly illustrated by the massive oeuvre of Leonard Cohen (1934-2016), a canonical writer-both poet and novelist-in Canada and a revered singer-songwriter in the rest of the world. In Cohen's oeuvre too, the idea of a single original is systematically under scrutiny. The same texts often appear in different versions: as a poem in a literary volume, as a song on a studio album or live album, or as a lyric in an anthology. The examples are ample. 'Suzanne' initially appeared as a poem and only afterwards as a song. The text of the song, 'The Window,' on the album Recent Songs (1979) differs from the version that was published in the anthology Stranger Music (1993). There are also some very well-known stories about the endless versions of Cohen's most famous hit 'Hallelujah' (on which he worked for more than five years and eighty couplets) or the two versions of 'Chelsea Hotel', of which only the second was kept on the album (the full title, as printed on the album sleeve, is therefore 'Chelsea Hotel \#2').

One should not forget that the artistic practice of the recentlydeceased Canadian likewise developed in two directions, literary and musical ${ }^{1}$. Cohen continued to write and make music until the end of his life and he consciously minimized the border between the two: he often mentioned that many of his songs were based on poems (some that he recited during his concerts) and from time to time he also invoked the "invisible guitar", that was perpetually hidden behind his poetry. The only difference, according to Cohen, between a poem and a song was that a song can appeal more directly

${ }^{1}$ In 1956 Cohen published his first poetry volume Let Us Compare Mythologies and about ten years later, in 1967, he released his first music album, Songs of Leonard Cohen.

Cad. Trad., Florianópolis, v. 39, nº 1, p. 145-167, jan-abr, 2019. 
to the audience. Unlike the sometimes quite cerebral experience of poetry, a song enhances "a (direct) movement from lip to lip and heart to heart" (Cohen, quoted in Adria).

In this contribution, I will study a fraction of Cohen's oeuvre, i.e. a complex corpus of four titles that, on the one hand, questions the existing definitions of retranslation and, on the other hand, indicates a number of (power) mechanisms at play in retranslations. Over the course of less than a decade, Leonard Cohen's Book of Longing (2006), was translated into French on three different occasions. This poetry collection was first translated in Québec (Livre du constant désir, 2007) and then in France (Le livre du désir, 2008). The Québécois translator is Michel Garneau, a recognized poet, playwright and translator, and Cohen's regular translator in French-speaking Canada for quite some time ${ }^{2}$. The French version was made by two translators: Jean-Dominique Brierre and Jacques Vassal. In the past, the two men worked together for the translation of Poèmes et Chansons I, an anthology of Cohen's poetry and music published in $1972^{3}$. In addition, seven poems published in Book of Longing appeared previously as songs in the studio album Ten New Songs $(2001)^{4}$. The French release of this album was accompanied by a promotional booklet, in which the original texts and French translations were printed. Those translations were carried out by Graeme Allwright, a singer-songwriter from New Zealand, who, in the early seventies, caused a stir in France with

\footnotetext{
${ }^{2}$ In 2000, Garneau published Étrange musique étrangère, a translation of Stranger Music (1993), previously translated in France by Jean Guiloineau as Musique d'ailleurs (1994).

3 This translation was made by two pairs of translators: next to Brierre and Vassal, Anne Rives and Allan Kosko also translated several poems. In 1984, Vassal translated also Book of Mercy (Le livre de miséricorde). Vassal promoted the reception of Cohen in France, both through many contributions in music magazines (such as Rock et Folk) and through translations in books and magazines. ${ }^{4}$ A similar thing happened for Dear Heather, the album from 2004. Five songs would later be published as poems in Book of Longing: 'Nightingale', 'The Faith', 'There for you', 'Because of a few songs', 'The letters'.
} 
his French adaptations of Cohen's work ${ }^{5}$. As a musician, he is one of the major mediators of Cohen's work in France. The editorial history could be summarized as follows ${ }^{6}$ :

\section{RESEARCH CORPUS : EDITORIAL TRAJECTORY}

\section{in ENGLISH in FRENCH}

[1.] 2001 [music album] Ten New Songs $\quad \begin{aligned} & + \text { translation by G. } \\ & \text { Allwright }\end{aligned}$

[2.] 2006 [poetry volume] Book of Longing

[NB. including 7 poems $^{7}$ previously released as songs on Ten New Songs]

[2.1] 2007 [translation for Québec]

Livre du constant désir

[2.2] 2008 [translation for France]

5 The French career of Graeme Allwright (1926-) took shape through a combination of private and professional motivations. In 1948, he travelled to London because he aspired to a theatrical career. There, he also met his wife, who was French, and after a while they moved to France, where Allwright practised a number of jobs (inside and outside the artistic sector), before he started his own singing career. In 1965, at the age of 39, he released his first album (Le Trimardeur). Shortly after, he set himself up as interpreter of American protest songs (Woody Guthrie, Pete Seeger) and started to make his first translations of Leonard Cohen's songs ('Suzanne' and 'The Stranger Song'). This way, he could gain the necessary visibility and credibility as a non-native French artist. His later translations of Cohen (e.g. his album Graeme Allwright chante Leonard Cohen, 1972) consolidated his position in the cultural field. According to journalist and author Jacques Vassal, "the growing reputation of Graeme Allwright is France was indirectly helped by the reputation of Cohen" (private interview, 15.04.2018). Just as Casanova explains that translation can play a consecrating role on a macrolevel (between (national) cultures), the same dynamics is here at work on an individual level: the prestige of the translated author reflects on the translator.

${ }^{6}$ One could add here two more titles: the album Book of Longing: A Song Cycle Based on the Poetry and Images of Leonard Cohen, made by Philip Glass in 2007, and Poèmes du traducteur, a poetry collection written by Garneau (in the capacity of writer) while he was translating Book of Longing. For this article, I have limited the corpus to the titles in which there was a reference to a French translation.

${ }^{7}$ Namely: 'A thousand kisses deep', 'Here it is', 'Love itself', 'By the rivers dark', 'Alexandra Leaving', 'You have loved enough', 'Boogie Street'. 
Although Cohen's family and professional roots are in Montreal and he often confirmed his predilection for his birth city, his career has always been more successful in Europe than in North America. The album Various Positions (1984), for instance, was not even released in the United States, although it contained a number of songs that would become real classics afterwards ('Dance me to the end of love', 'Hallelujah', 'If it be your will', etc.). The European tradition of troubadours and later on 'chansonniers'-'paroliers' and singer-songwriters gave birth to a 'repertoire' (Even-Zohar) in which the musical oeuvre of Cohen was bestowed with more visibility and recognition than in North America, where another tradition (of 'crooners') became more important.

\section{2. 'Retranslation': a concept challenged}

To what extent can these texts be labeled as retranslations? To begin with, the chronology of the four versions challenges the traditional definition of retranslation. According to Koskinen \& Paloposki, '[c]ommon sense explanations for retranslation tend to focus on the ageing and allegedly outdated features of the previous translation' (296). In the case under consideration, this motivation is not relevant, given that the three translations appeared almost simultaneously. Moreover, the publication date of Book of Longing was preceded by a long writing process: several texts were written long before 2006 (some poems indicate their date of writing - the oldest text dates back to 1973) and the composition of the volume took several years (the volume was nicknamed Book of Prolonging). Amongst other things, this means that the different tracks of Ten New Songs were available quite some time before 2001, albeit as poems, and the musical composition took place afterwards. The poem/song 'Thousand kisses deep' is an interesting example. In Book of Longing, two versions of the poem are printed on facing pages. Strikingly, the version which appeared first chronologically (as a song on Ten New Songs) is presented on the right side, giving 
the impression of being released later than the version on the left, which was in fact printed for the first time in Book of Longing. An important effect of this unclear chronology and of the migration of texts between cultural systems and institutional contexts is a resultant ambiguity of status (music and/or literature) which in turn influences translation and/or (re)writing strategies. I will come back to this later (see point 4).

By contrast, it is tempting to brush off these attempts as "passive retranslations $^{8}$, (Pym 82-83) simply because they target different audiences: on the one hand, there is the geographical (and, hence, cultural) difference (France for Vassal-Brierre and Québec for Garneau) and on the other hand, the artistic orientation (poetry readers for Vassal-Brierre and Garneau vs. music listeners for Allwright). Despite the fast succession of the three publications, the notion of 'retranslation' is never mentioned in the (para)text. Moreover, in the Brierre-Vassal-translation there is even no reference to the previously published Québec-translation. This may be due to the fact that the three translations were released and read independently from each other and because one could talk of an 'adaptation' instead of a 'retranslation' when comparing the musical and literary work with each other'. However, this raises two connected issues.

a. First of all, the three translations are not entirely unconnected. Before the remarkable editorial trajectory of the

8 Anthony Pym defines "passive retranslations" as simultaneous translations for different markets, whereas "active retranslations" compete for the same audiences. 9 I encounter here a problem that has already been mentioned by others: "Addressing retranslation as an object of study in its own right involves the task of conceptualization. This endeavor has been only partially embraced by scattered studies that address the relation of retranslation to previous translations, different source texts, revisions, new editions, reprints, adaptations, backtranslation or indirect translation [...]" (Alvstad \& Assis Rosa, 8). The renewed attention for the phenomenon of retranslation (of which this special issue is a clear illustration) is hopeful, just as the organization of first international interdisciplinary conference on 'Intersemiotic translation, Adaptation, Transposition: Saying Almost the Same Thing?' (University of Cyprus, November 10-12, 2017). 
Book of Longing-translations, a "confrontation" between the French and the Québécois audience had already happened. Indeed, the first Québécois translation of Cohen's poetry, Étrange musique étrangère, was published as a reaction against Musique d'ailleurs, a previously released French translation of Stranger Music (the anthology of literary and musical texts that had a negative reception in Québec, see footnote 2).

Next to that, the two French translations from Book of Longing (Vassal-Brierre and Allwright), despite their different nature, serve the same single goal: making the text understandable for a Frenchspeaking audience. This has not always been the case. Allwright's translations from the seventies fulfilled two functions: they were not only meant to clarify the content of the songs, but they were also meant to be sung. On the back cover of his album Graeme Allwright chante Leonard Cohen (1973), Allwright labels his translations as (musical) "adaptations" and explains his aim to make the work of Cohen accessible for a French-speaking audience:

En adaptant ces chansons, j'ai essayé de respecter dans la mesure du possible la pensée de Leonard Cohen que j'estime beaucoup. J'espère que mon travail aidera l'auditeur français à mieux comprendre et pénétrer l'univers souvent difficile de Cohen.

Because of those two objectives, he could not always choose the most literal translation and was forced to translate the 'spirit' rather than the 'letter' of the songs. In an interview from that period, he declares:

La première fois que j'avais entendu son deuxième disque, Songs From a Room, j'avais eu l'impression d'avoir écrit les chansons moi-même. C'est sans doute pour ça que j'ai pu traduire cet esprit, bien qu'il reste des aspects encore mystérieux. (Allwright 26) 
In music magazines of the same period, other translations were published although they were not meant to be sung. It is remarkable that the need to translate the lyrics was explicitly formulated several times: journalists asked translators to translate the lyrics and publish them (see also Mus 2017). Today, translations of lyrics in reviews are rather rare. In this regard, Susam-Saraeva (192) indicates that one reason for this is that "non-translation in the case of music may allow the imagination more leeway (...)". In one of his translations for Rock et Folk, Jacques Vassal (74) remarked:

Traduire des chansons de Leonard Cohen, il y a bien longtemps que nous en avions envie. L'ennui, comme beaucoup se plaisent à le répéter, c'est que la subtilité particulière de son langage, l'audace des images dans ses poèmes et chansons (je ne parle pas ici des romans, qui posent des problèmes de traduction fort différents), rendent l'opération assez périlleuse. D'autant plus qu'en général, le passage de l'anglais moderne au français ne s'effectue déjà pas sans douleur. Par conséquent, les trois textes ci-dessous [Stories of the street, The old revolution, Famous blue raincoat] ne représentent que notre modeste contribution à une meilleure compréhension de la pensée de Cohen, destinée surtout à ceux qui, ne sachant pas toujours l'anglais, nous écrivent dans ce sens. On le voit, il ne s'agit EN AUCUN CAS d'un exercice littéraire, ni d'adaptations françaises chantables (pour cela, il faudrait plutôt s'inspirer de l'œuvre de Graeme Allwright)

For the translations under study here, this distinction made by Vassal is not valid, given the fact that Allwright never used his translations of Ten New Songs for a musical adaptation into French.

b. On the other hand, the similarities and the differences between the three texts offer a unique opportunity to reveal a number of power mechanisms between both the dynamics of centre-periphery 
(France and Québec) and the production of highbrow-lowbrow cultural products (literature and music). In what follows, I will first compare the two poetry collections, and then include the translation of Allwright in my analysis in order to formulate several hypotheses that could explain, at least in part, the differences between these three versions.

\section{Institutional embedding and translation strategies: some hypotheses about Livre du constant désir (2006) and Livre du désir (2008)}

\subsection{First opposition: Explicit vs. Implicit | Local vs. Universal}

Étrange musique étrangère, the Québécois translation of Stranger Music (1993), was the first collaboration between Cohen and Garneau ${ }^{10}$. With the appearance of Book of Longing, the plan to create a separate translation for Québec existed from the outset. As such, the Québécois version was published very quickly - in the same year as the original publication. The mere comparison of the titles shows us that Garneau is much more explicit in his translation. In this regard, Antoine Berman makes a distinction between two different forms of explicitation. The first one, negative, consists of the movement from polysemy to monosemy. The other form, positive, is 'the manifestation of something that is not apparent, but concealed or repressed, in the original' (Berman 245). The

${ }^{10}$ Garneau and Cohen had known each other since their youth, amongst other things via the brother of Michel Garneau, who just like Cohen was a poet in the fifties. Although in the 1960s Cohen himself would make a (French to English!) translation (he translated the subtitles of $A$ tout prendre, a movie made by Claude Jutra, see Mus 2016), he would never translate again in a public or professional context, and certainly not into French. In 1975, he said: 'I don't speak French that well. I can get by, but it's not a tongue I could ever move around in a way that would satisfy the appetites of the mind or heart'. (Cohen 1975, in Burger 85).

Cad. Trad., Florianópolis, v. 39, nº 1, p. 145-167, jan-abr, 2019. 
translation of the titles of the two poetry collections shows clearly that for Garneau, it is the second type of explicitation that is at play:

\begin{tabular}{|l|l|l|}
\hline COHEN & FRANCE & QUÉBEC \\
Stranger Music & $\begin{array}{l}\text { Musique d'ailleurs } \\
\text { (Guiloineau) } \\
\text { Be livre du désir } \\
\text { (Vassal-Brierre) }\end{array}$ & $\begin{array}{l}\text { Etrange musique étrangère } \\
\text { (Garneau) } \\
\text { Livre du constant désir } \\
\text { (Garneau) }\end{array}$ \\
\hline
\end{tabular}

The title Le livre du désir appears as fairly neutral (because of a highly formal lexical equivalence), while Garneau each time adds a word ("étrange" and "constant"), by which he makes his title more explicit. He emphasizes the existential condition of the artist, who feels completely and existentially alienated. Longing has become a chronic condition. Unlike the French translators, he intervenes more in his translation, although different interpretations of the translated title remain possible. Contrary to Vassal and Brierre, Garneau does not add the article 'Le'. Both for Book of Longing as for Book of Mercy (his previous poetry book, published in 1984), Cohen stressed in interviews that he omitted the article on purpose in order not to suggest any kind of definitive character of his work.

In the rest of the paratextual information, Garneau is again much more explicit than his French colleagues. In the French edition, Cohen is rather vaguely introduced as a universal poet whose work transcends national boundaries. On the back cover, one reads: "Leonard Cohen [...] est d'abord un poète, universel [...] On retrouve dans Le livre $d u[d]$ ésir de multiples traces des voyages de Leonard Cohen et de ses explorations spirituelles» (my emphasis). On the cover of the Québécois edition, Cohen's hometown, Montreal, is mentioned, as well as California, where he lived later in his life. In the press, Garneau emphasized the poet's origin: "Leonard Cohen, c'est un poète montréalais. C'est un artiste qui a été particulièrement marqué par Montréal” (Garneau, in Montpetit). 
In sum, the analysis of the paratext shows that, on the one hand, Garneau emphasizes the local roots of Cohen (a detail omitted by the French translators), on the other hand he further pursues his existential condition as an alienated and wandering artist, by relating the adjectives in the title to the fundamental living condition of its author. I want to stress here that, whereas we can connect the explicit/implicit dichotomy exclusively to a translator's strategy, the binaries of local/universal and noble/vulgar language (cf. below) are both fundamental for the style and poetics of Cohen's literary and musical oeuvre (see also Mus 2016).

\subsection{Noble vs. vulgar}

A second opposition that distinguishes the two translations from each other has been studied recently by Tanasescu \& Alberti (2016), and concerns the distinction between noble (or elevated) and vulgar language use, which is visible at several levels. Tanasescu \& Alberti demonstrate convincingly that the French translations have a higher register. For example, there is the frequent use of capitals and a more composed, poetic translation on a lexical and grammatical level, in particular the choice of the passé simple (a literary tense, which cuts off the past from the present) with Vassal-Brierre and the imparfait with Garneau. A journalist once confronted Garneau and Vassal-Brierre with their translations. They discussed the translation of a word in an ambiguous verse of the poem 'Collapse of Zen', in which Cohen talks in covert terms about the feminine genitals:

When I can wedge my face

into the place

and struggle with my breathing

as she brings her eager fingers down

(...) 
"The place" was translated by Vassal-Brierre as "le lieu des lieux" (a paraphrase of "le saint des saints"), while Garneau opted for "la bonne place". According to Garneau, the translation of his colleagues lacked the sexual ambivalence of "the place". "Je n'ai rien contre", he said, "mais c'est pas cochon. Et Leonard, il est cochon!". These observations also apply to the seven poems that previously appeared on Ten New Songs. The elevated language use in Vassal-Brierre is also reflected in their choice to retain more rhyme schemes than Garneau (though none of the translators choose to retain rhyme systematically). The following example (taken from "You have loved enough") explains the deliberate reversal of word order 'vient la haine' / 'la haine vient' in:

\begin{tabular}{|l|l|}
\hline COHEN & VASSAL-BRIERRE \\
$\begin{array}{l}\text { (...) I am not the one who loves } \\
\text { It's love that seizes me. } \\
\begin{array}{l}\text { When hatred with his package } \\
\text { comes } \\
\text { You forbid delivery. }\end{array}\end{array}$ & $\begin{array}{l}\text { (...) ce n'est pas moi qui aime } \\
\text { C'est l'amour qui s'empare de moi. } \\
\text { Quand avec son paquet vient la } \\
\text { haine, } \\
\text { Tu interdis la livraison. }\end{array}$ \\
\cline { 2 - 2 } & GARNEAU \\
& $\begin{array}{l}\text { (...) je ne suis pas celui qui aime } \\
\text { C'est l'amour qui se saisit de moi. } \\
\text { Quand la haine vient avec ses } \\
\text { paquets, } \\
\text { Tu en interdis la livraison. }\end{array}$ \\
\hline
\end{tabular}

This way, the Vassal-Brierre translation keeps some aspects of the original rhyme. Their text creates a formal connection between love and hate-'aime' and 'haine' - by using them as the final words in a rhyming couplet. Such a connection is a trademark in the rest of Cohen's oeuvre (think of Songs of Love and Hate (1971), for instance).

A similar example is the translation of the title 'Alexandra leaving' as 'Alexandra s'en va' by Vassal-Brierre and 'Alexandra 
s'en allant' by Garneau. The Frenchmen create a rhyme that is not there in the title, but indeed in the rest of the song. The attention to musicality in Vassal-Brierre is mostly based upon a visible, "faithful" imitation of the original (rhyme, for example), while Garneau claims for himself the freedom to create his own version of musicality, even though this would mean that he has to make a choice of translation that cuts across the structure of the source text. Take the opening lines of the titular poem, 'The Book of Longing': Cohen uses a personal pronoun several times, which is taken over by Vassal-Brierre but not by Garneau. By omitting the first person pronouns, Garneau manages to evoke fatigue at the semantic level and also in the syntax of his translation (see also Tanasescu \& Alberti 243):

\begin{tabular}{|l|l|l|}
\hline COHEN & VASSAL-BRIERRE & GARNEAU \\
& & \\
I can't make the hills & Je n'arrive pas aux collines & Peux plus monter les côtes \\
The system is shut & Le système est flingué & Le système a lâché \\
I am living on pills & Je vis de pilules & Servi aux pilules \\
For which I thank G-d & Et j'en remercie Di-u & Dont rends grâce à D-u \\
\hline
\end{tabular}

\section{Ten New Songs in comparison to the two book translations}

In what way does the French translation of Ten New Songs relate to the two previous translations? While the translations of Garneau and Vassal-Brierre differ in their tendency to make the text more explicit/local/vulgar (G) or, on the other hand, implicit/ universal/elevating (VB), the translation of Allwright offers a strange mix between these two extremes. On the one hand, unlike Vassal-Brierre, Allwright never uses a passé simple and never chooses to maintain the rhyme. On the other hand, his translation differs from that of Garneau because the choice of words is not always entirely explicit. All in all, one could situate his translation 
strategies between the more 'outspoken' versions of Garneau and Vassal-Brierre. Take this example from 'Boogie Street':

\begin{tabular}{|l|l|}
\hline COHEN & VASSAL-BRIERRE \\
I'm turning tricks I'm getting fixed & J'ai mes combines je me fais rouler \\
\hline $\begin{array}{l}\text { GARNEAU } \\
\text { Je fais la pute je prends ma drogue }\end{array}$ & $\begin{array}{l}\text { ALLWRIGHT } \\
\text { Je vends mon âme, j'achète le rêve }\end{array}$ \\
\hline
\end{tabular}

The lexical choices are situated on three levels here, ranging from rather vulgar (Garneau) to rather noble (Vassal-Brierre) and, finally, a more intermediary variant (Allwright). Other examples confirm that Allwright's version is situated between those of Vassal-Brierre and Garneau. In the song 'Love itself' one is struck by the various translations of the verbal constructions. These are the original lyrics:

The light came (1) through the window,

Straight from the sun above,

And so inside my little room

There plunged the rays of Love.

In streams of light I clearly saw (2)

The dust you seldom see,

Out of which the Nameless makes (3)

A Name for one like me.

I'll try (4) to say a little more:

Love went on and on

Until it reached an open door -

Then Love Itself

Love Itself was gone (5).

All busy in the sunlight

The flecks did float and dance,

And I was tumbled up with them

In formless circumstance. 
Then I came back (6) from where I'd been.

My room, it looked the same -

But there was nothing left (7) between

The Nameless and the Name.

Quite often, Garneau (G) and Allwright (A) opt for a similar translation choice, both on a grammatical and on a lexical level. For example, they use passé compose instead of passé simple: 2 - j'ai vu (G,A) / je vis (VB); 6 - je suis revenu (G,A) / je revins $(\mathrm{VB})$ ); or they prefer single word translation: 1 - traverser $(\mathrm{G}, \mathrm{A})$ / entrer (VB); 3 - donner $(\mathrm{G}, \mathrm{A})$ / peut faire $(\mathrm{VB}) ; 7$ - rester $(\mathrm{G}, \mathrm{A})$ / demeurer $(\mathrm{VB})$. Sometimes, when one passage is rendered in three different translations, there can be a three-fold difference in the use of elevated language: Vassal-Brierre use an elevated language, Garneau chooses a vulgar translation and Allwright opts for a more neutral word. For example: 4 - VB opt for 'je tâcherai', whereas Garneau and Allwright choose a more standard verb, in a formal and informal verb construction: j'essayerai (G) vs. je vais essayer (A); 5 - VB opt for 'disparut', whereas Garneau chooses a common verb 's'en est allé' (passé compose) and Allwright combines the lexical choice from VB and the grammatical choice from Garneau : 'a disparu'.

How can we explain these differences? Focusing on the difference of register, one can ask why the translation of Allwright, who lives and works in France, more closely resembles the Garneau version than the Vassal-Brierre version? A first explanation is banal: it seems that the Allwright-booklet was quickly arranged and designed for promotional purposes. Here and there one can even notice an error or typo. There is no clear strategy behind these commercial translations: these supplements were published only twice - for The Future (1992) and for Ten New Songs (2001).

A second explanation is more fundamental. My hypothesis is that the institutional context can explain the difference in translation strategy: unlike poetry, the music of Cohen belongs to a rather popular genre in which a "simpler" (less elevated) translation 
seems more appropriate. However, the mere fact that these translations of lyrics do exist, shows at the same time that Cohen's work also transcends the status of banal entertainment music. This could also explain why some of the recent shows in France were subtitled: translations of the lyrics were projected on large screens, resembling what happens in opera subtitling or poetry readings canonized genres par excellence - but rarely during pop concerts.

It goes without saying that many differences between the French and the Québécois versions can simply be explained by cultural differences and language varieties between Québécois French and metropolitan French - hence the overtly local dimension in the translation of Garneau. While there are cases where ennoblement is an unconscious or even arbitrary phenomenon-Berman (246247), for instance, sees it as characteristic of (literary) translation in general-the comparison of these translations and the source text reveals the significance of their respective contexts. The Book of Longing translations are marked by a particular institutional context, which seems to justify the hypotheses mentioned above. Indeed, there is a two-fold power dynamic at play, manifesting itself from a geographic perspective (Québec vs. Paris) and from an artistic perspective (poetry vs. popular music).

The earlier history of other translations of Cohen point to a language / translation sensibility of which the translators must have been aware. On the one hand, the first Québécois translation of Cohen's poetry, Étrange musique étrangère, was indeed inspired by comments from the master himself: "Mon français est juste assez bon pour savoir que ces traductions [françaises] deviennent ridicules au Québec: je voudrais une traduction pour le Québec" (in Monette, 32). In other words, it was the author who granted the translator a creative space in which he could carry out his translation. On the other hand, the profile of the translator can also explain a number of translation choices: Garneau is himself a writer and, through his translation practice, he was pioneer in the identity development of Québec society. Brisset includes Garneau in her study of the interaction between identity formation 
and translation practice in Québec, where "Translation becomes an act of reclaiming, of recentring of the identity, a reterritorializing operation. It does not create a new language, but it elevates the dialect to the status of a national and cultural language" (2000, 284). As classic example, she mentions Garneau's translation of Macbeth from the seventies. In the paratext of his Macbeth, Garneau did not add information about the source language ("traduit de l'anglais", for instance, as is customary), but about the target language: "traduit en Québécois". Translation becomes an instrument mobilized in an identity process.

In the thirty years between translating Macbeth and Book of Longing, much has changed. In Livre du constant désir, only the name of the translator is mentioned: "traduction par Michel Garneau". Moreover, one should not forget that Garneau's literary practice, as a writer or as a translator, was never focused exclusively on the promotion of a single Québécois identity. His work constituted an indictment of the dominant discourse that advocated a monocultural Québécois identity: "The poetry of Michel Garneau opposes the fascist undertones of such rhetoric. His apologia for cross-breeding uses poetic language to reveal and acclaim the mixed background of Québécois identity" (Brisset 2000, 290, my emphasis). In 1974, the poet writes explicitly: “qu'on réalise Québécois combien nous sommes / écoeuremment racistes". In the poem 'Les regards' (2011), he praises precisely the international openness of the generation of artists of which Cohen was a part : "Cohen avait l'anglais pour le porter vers le monde, / $\mathrm{Au}$ PamPam $^{11}$, il y avait des bilingues, des polyglottes (...)”. For some Canadian critics, such as Malcolm Reid, Cohen's international (i.e. non exclusively local) dimension is indeed seen as problematic. Sherry Simon (39) summarized Reid's opinion thoroughly: "the desire for the universal, against the unresolved demands of the local, is interpreted as a betrayal of the political struggle".

11 «Le PamPam » was a Hungarian restaurant on rue Stanley (Montreal) where Cohen often used to go.

Cad. Trad., Florianópolis, v. 39, nº 1, p. 145-167, jan-abr, 2019. 
The explicitness in the recent translation of Book of Longing can also be interpreted, from a hermeneutical perspective as opposed to a purely institutional explanation - as an attempt to render in translation the fundamental heterogeneous nature of Cohen's own works: both local and universal, both noble and vulgar. In this respect, the work of Garneau distinguishes itself in the same way, both from a dominant Québécois discourse and from a typical French discourse, in which the tendency for homogenisation overrides heterogenisation (see also Casanova 2002). On the other hand, seen from an external point of view, one could also label Garneau's retranslation as "confrontational" (Alvstad \& Assis Rosa, 10) and even recognize a "surécriture" (Denis and Klinkenberg, 61), i.e. a kind of compensation strategy that consists of challenging the linguistic and literary norms by suggesting an adventurous or sometimes even a provocative translation, both on a lexical and syntactical level.

In this regard, it is difficult to compare the 'booklet'-translation of Allwright with the book-translations of Garneau and VassasBrierre. Allwright's work could be seen as 'secondary', both on an institutional level (the translation as a promotional booklet) and on a functional level (the translation does not serve any artistic (poetic or musical) purpose but is purely informative). Moreover, the (literary) symbolic capital of Allwright is not as big as that of Garneau or Vassal/Brierre, who occupy other positions as writer, journalist or historian in the literary field. As a consequence, Allwright's translation had less visibility and less impact.

\section{Conclusion}

At first sight, the institutional differences between the translations of Vassal-Brierre, Garneau and Allwright offer a sufficient explanation for their almost simultaneous publication: each time, they were carried out for a different target audience: literary or musical, French or Québécois. However, this explanation is incomplete. 
According to Alvstad \& Assis Rosa (12), "Synchronic retranslations may be produced with the purpose of offering a different rendering or interpretation of a source text, fulfilling a different function, or addressing a different readership or audience". The analysis of this complex corpus has shown that the different institutional contexts do have an influence on the translation strategies (e.g. the tendency to translate in a less elevated way for musical (i.e. non-literary) translations), thus foregrounding or backgrounding several aspects of Cohen's work.

Indeed, Leonard Cohen's oeuvre is characterized by a number of fundamental oppositions, two of which have been mentioned here: the tension between a local and a universal dimension and the tension between a noble and a vulgar style. Although earlier fundamental translation research has already pointed out that translations are often more explicit and nobler than their source texts, the comparison of different translations has shown that several degrees of explicitation or ennoblement are possible.

Although the extent to which the translator realizes these tendencies can vary, one should add that other factors may also neutralize or reinforce these general tendencies. These factors can be internal (motivated by a specific interpretation of the source text) or external (e.g. the political (identity) role of translations). In this regard, the Garneau-translation is the most remarkable one. His profile as a well-known advocate of the Québécois identity, as a writer himself and a friend of Cohen, allows for an interpretation according to which translation choices can be interpreted in a strategic way (distinction, surécriture, etc.) but the study of the source text and the paratexts of the translations have also shown that the translation choices can equally be motivated by a specific interpretation of the oeuvre of Cohen, i.e. by highlighting the "local ground' of his artistic (and not only biographic) universe and the continuous coexistence between both the local and the universal, and the vulgar and the noble in his works. 


\section{References}

Adria, Marco. “Aurora Online with Leonard Cohen.” Aurora Online, 1990, http:// aurora.icaap.org/index.php/aurora/article/view/36/47. Accessed 21 Sept. 2017.

Allwright, Graeme. Graeme Allwright chante Leonard Cohen, Mercury, 1973.

. "Des images mystérieuses - interview by Jacques Vassal". Paroles et Musique, 33, 1983, p. 26.

Alvstad, Cecilia. Assis Rosa, Alexandra. "Voice in retranslation. An overview and some trends." Target, vol. 27, no. 1, 2015, pp. 3-24.

Berman, Antoine. "Translation and the trials of the foreign " The Translation Studies Reader (third edition), edited by Lawrence Venuti, Routledge, 2000, pp. 240-253. $\overline{1990, \text { pp. } 1-7 .}$

. "La Retraduction comme espace de traduction." Palimpsestes, no. 4,

Brierre, Dominique, translator. Vassal, Jacques, translator. Le livre du désir. By Leonard Cohen, Le Cherche Midi, 2008.

Brisset, Annie. «Retraduire ou le corps changeant de la connaissance. Sur l'historicité de la traduction. » Palimpsestes, no. 15, 2004, pp. 39-67.

. «The search for a native language: translation and cultural identity. » The Translation Studies Reader (third edition), edited by Lawrence Venuti, Routledge, 2000, pp. 281-309.

Burger, Jeff. Leonard Cohen on Leonard Cohen: Interviews and Encounters. Chicago Review Press, 2014.

Casanova, Pascale. "Consécration et accumulation de capital littéraire. La traduction comme échange inégal. »Actes de la Recherche en Sciences Sociales, no. 144, 2002, pp. 7-20. 
Cohen, Leonard. Book of Longing. McClelland and Stewart, 2006.

Denis, Benoit. Klinkenberg, Jean-Marie. La littérature belge. Précis d'histoire sociale. Espace Nord, 2005.

Gambier, Yves. "La retraduction, retour et détour. » Meta, vol. 39, no. 3, pp. 413-417.

Garneau, Michel, translator. Etrange musique étrangère. By Leonard Cohen, L'Hexagone, 2000.

, translator. Livre du constant désir. By Leonard Cohen, L’Hexagone, 2007.

. Poèmes du traducteur. L'Hexagone, 2008.

p. 7.

. «Les regards. » Revue de la Société historique de Montréal, n62, 2011,

Glass, Philip. Book of Longing. A Song Cycle Based on the Poetry and Images of Leonard Cohen, Orange Mountain Music, 2007.

Guiloineau, Jean, translator. Musique d'ailleurs. By Leonard Cohen, Christian Bourgois, 1994.

Koskinen, Kaisa. Paloposki, Outi. "Retranslation." Handbook of Translation Studies, Volume 1, edited by Yves Gambier \& Luc van Doorslaer, John Benjamins, 2010, pp. 294-298.

Monette, Pierre. "Un poète et son traducteur, le traducteur et ses poèmes." Entre les lignes : le plaisir de lire au Québec, vol. 5, n² 2, 2009, p. 32.

Montpetit, Caroline. "Leonard Cohen ou la constant quête de beauté ", Le Devoir (May 5, 2007), http://www.ledevoir.com/culture/livres/142205/leonard-cohenou-la-constante-quete-de-beaute. 
Mus, Francis. “'There's nothing to follow, there's nowhere to go'. Errance et arrêt dans l'œuvre de Leonard Cohen." Les révolutions de Leonard Cohen, edited by Chantal Ringuet, Presses de l'Université du Québec, 2016, pp. 53-71.

. "Leonard Cohen in French Culture : a Song of Love and Hate. A Comparison between Musical and Literary Translation", submitted, JosTRans, $\mathrm{n}^{\circ} 29,2018$, http://www.jostrans.org/issue29/art_mus.php.

Pym, Anthony. Method in Translation History. St. Jerome, 2008.

Simon, S. Translating Montreal. Episodes in the life of a Divided City, 2006, McGill Queen's University Press.

Susam-Saraeva, Sebnem. "Translation and Music. Changing Perspectives, Frameworks and Significance. » The Translator, vol. 14, no. 2, 2008, pp. 187-200.

Tanasescu, Raluca. Alberti, Louis. "Leonard Cohen: un auteur majeur et ses traducteurs 'en mode mineur'. " Les révolutions de Leonard Cohen, edited by Chantal Ringuet, 2016, Presses de l’Université du Québec, pp. 229-252.

Vassal, Jacques. « Histoires de la rue. » Rock et Folk, n 58, 1971, pp. 74-76.

Recebido em: 18/09/2018

Aceito em: 13/11/2018 Publicado em janeiro de 2019

Francis Mus. E-mail: francis.mus@ulg.ac.be ORCID: https://orcid.org/0000-0003-0369-002X 